and Ludwigshafen in the lower Rhine valley, were both felt with intensity 7 on the Modified Mercalli scale. On February 22 an earthquake took place with epicentre near Winster in Derbyshire. Chimneystacks collapsed and walls of buildings, chiefly in the main street, collapsed; some slight damage was done in the surrounding district, and it is likely that movement took place along the Crich-CromfordBonsall fault. The shock was accompanied by a sound like a double explosion. On March 9 an earthquake was felt with intensity 8 at Etna in Sicily, and on the same day a strong one occurred in north-west Turkey. An earthquake with intensity 7 was felt on May 20 at El Palmar in Spain. Shocks with intensity 8 occurred on June 8 at Pierre Longue (France), on June 13 at Perivola (Peloponnese Islands) and on June 26 at Riberra Quente, Azores. On September 29 an earthquake was felt with intensity 7 at Munchhausen and Soufflenheim in the lower Rhine valley, and on October 8 there wass a shock in lower Alsace with the same intensity. Twelve people were killed and a hundred injured on October 22 in an earthquake in the Adana district in Turkey.

Other earthquakes causing property damage and casualties occurred as follows. On July 21 in the Tulare Valley in southern California an earthquake caused extensive damage and several people were killed. The town most seriously affected was Tehachapi, some hundred miles north of Los Angeles. Permanent vertical ground movement at Bear Mountain fault was as much as one metre. On October 14 an earthquake from an epicentre at lat. $8.5^{\circ} \mathrm{N}$., long. $83^{\circ} \mathrm{W}$., near the south coast of Costa Rica, resulted in casualties and property damage, as did one on October 28 in Haiti (epicentre at lat. $18.5^{\circ}$ N., long. $73.5^{\circ}$ W.). On November 22 an earthquake caused slight property damage in San Luis Obispo County, California.

Reports have been received from the United States Coast and Geodetic Survey in co-operation with Science Service and the Jesuit Seismological Association, the International Seismological Association at Strasbourg, and from observatories at Aberdeen, Arkansas, Beograd, Cleveland (Ohio), De Bilt (Netherlands), Durham, Fayetteville (U.S.A.), Karlsruhe, Kew, Pasadena, Perth (Western Australia). Stuttgart, Toledo, Wellington and the New Zealand stations (including Fiji), and Zurich and the Swiss stations.

ERnest TrLLOTSON

\section{EDUCATION IN INDIA}

T HE first elections in free India under universal suffrage showed that a large proportion of voters had voted not for any particular cause, or person, but for the sacred bull (Science and Culture, 18, No. 1 ; July 1952). Congress, which now holds power, had long been mindful of the importance of educational reforms. So far back as the Karachi session of the Indian National Congress of 1931, a resolution was passed defining the fundamental rights of citizens and stating in its preamble that to enable the masses to appreciate what Swaraj would mean to them, Congress should provide for free and compulsory education.

Since independence, the National Government has been seriously tackling this problem. A large number of committees was appointed to consider general educational matters. Among them was the Kher Committee, which recommended that: (1) a fixed percentage of central and provincial revenues-about 10 per cent of the central and 20 per cent of the provincial-should be earmarked for education by the respective Governments; (2) about 70 per cent of the expenditure on education should be borne by Provincial Governments, including local bodies, and the remaining 30 per cent by the Central Government; (3) all contributions for education approved by the Provincial and Central Governments should be exempted from income tax.

The percentages recommended by the Kher Committee were not large. In certain States of the United States of America, nearly 30 per cent is spent on education, and in one State nearly 40 per cent. Apart from Mysore, which was already spending a larger percentage on education, no other major State, excepting a few like Bombay and Madras, have given serious attention to the Kher Committee's recommendations.

A comparison of State finances for 1951-52 shows that the total educational budget of all the States: amounted to Rs. 65 crores, which is about $14.8 \mathrm{pel}^{*}$ cent of the total budgets of the various States against. the Kher Committee's recommendation of 20 per cent. From these figures it is clear that the attempts to remove 'illiteracy' in the Indian Union has fallen short of the objective of Congress.

When Shri B. G. Kher's Committee recommended that 10 per cent of the central budget should be spent on education, it was implied that the bulk of it should be spent on higher and professional education. Ten per cent of the central budget comes to 30-40 crores of rupees, while the actual expenditure by the Central Government has varied between 3 and 6 crores.

The University Commission, appointed by Government on November 4, 1948, supported the National Planning Committee and Kher Committee's recommendation that democracy depends for its very life on a high standard of general, vocational and professional education. The academic problem has assumed new shapes. India now has a wider conception of the duties and responsibilities of universities. "They have to provide leadership in politics, administration, the professions, industry and commerce. They have to meet the increasing demand for every type of higher education, literary and scientific, technical and professional. It is for the universities to create knowledge and train minds who would bring together material resources and human energies.'

The Commission found that the universities were unable to carry out these responsibilities because their finances were totally inedequate.

Like the Kher Committee, it recommended that the Central Government should make large grants for higher education through a properly constituted agency.

The Commission is aware that the Central Government has taken the responsibility of maintaining the Universities of Banaras, Aligarh and Delhi (and now, the Visva Bharati), and that a large amount of money has been given as grants to meet the needs of these universities. While welcoming and appreciating the grants that have so far been given, the Commission has suggested that, even though grants to other universities are mainly provincial responsibilities, they should also be the concern of the Central Government at least so far as postgraduate education and 
research are concerned. The Commission noted with appreciation that grants to universities have been given by the Government of India in recent years, but hoped that there would be a more systematized method of giving these grants on the advice of a responsible body.

\section{MICROSOMAL PARTICLES OF NORMAL COW'S MILK}

\author{
By DR. R. K. MORTON
}

Biochemical Laboratory, University of Cambridge*

$\mathrm{H}$

ITHERTO, cow's milk has been considered to contain particulate components belonging to three categories, namely : (1) blood cells, leucocytes, bacteria and other readily sedimentable 'foreign' material; (2) butterfat globules; and (3) particles of the casein-calcium phosphate complex. However, it has recently been shown that lipoprotein particles, with which the alkaline phosphatase is firmly assoeiated, also oceur in milk ${ }^{1,2}$. Disruption of the lipid-protein bonds by treatment with $n$-butanol releases the alkaline phosphatase into true solution $n^{1,3}$.

In order to obtain the lipoprotein particles, whole milk was centrifuged $(2,500 \mathrm{~g}, 45 \mathrm{~min}$.) and the cream layer removed and repeatedly washed with distilled water. After churning, the buttermilk so obtained was centrifuged at high speed $(14,000 \mathrm{~g}, 45 \mathrm{~min}$.). The red-brown lipoprotein precipitate was then dispersed in distilled water.

The separated milk was also centrifuged under similar conditions to obtain a pure white precipitate of casein. In this way both the lipoprotein and casein complexes were isolated by methods expected to produce only a minimum of denaturation or other modification, although the recovery was by no means quantitative.

The properties of the two materials are compared in the accompanying table.

Comparative Propertiks of Casein AND IIPOPROTEIN Particles OF NORMAL COW'S MIEK

\begin{tabular}{|l|c|c|}
\hline & Casein particles & $\begin{array}{c}\text { Lipoprotein } \\
\text { particles }\end{array}$ \\
\hline $\begin{array}{l}\text { Lipid (per cent) } \\
\text { Nycleic acid }\end{array}$ & $\begin{array}{c}22 \\
\text { Cytochrome } c\end{array}$ \\
$\begin{array}{l}\text { Enzymic activities : } \\
\text { Alkaline phosphatase }\end{array}$ & $\begin{array}{c}\text { Not determined } \\
\text { Absent }\end{array}$ & $\begin{array}{c}\text { Present } \\
\text { Present }\end{array}$ \\
Coenzyme I-cytochrome $c$ & $0 \cdot 6$ & $57 \cdot 2$ \\
reductase & Absent & $2 \cdot 5$ \\
Xanthine oxidase & Absent & $0 \cdot 1$ \\
Cuccinic dehydrogenase & Absent & $37 \cdot 7$ \\
& Absent & Absent \\
Absent & & \\
\hline
\end{tabular}

Units for enzymic activities: alkaline phosphatase expressed as $\mu$ mole phosphorus liberated from $\beta$-glycerophosphate $/ \mathrm{hr}$. $/ \mathrm{mgm}$. nitrogen
(at $37^{\circ} \mathrm{C}$.); dehydrogenases expressed as $\mu$ mole $2: 6$-dichlorophenol indophenol (diaphorase and xanthine oxidase) or of cytochrome $c$ (coenzyme I-cytochrome $c$ reductase) reduced/hr./mgm. nitrogen (at

The difference between the two protein complexes is immediately apparent. The relatively high lipid content (most of which is phospholipid) and the considerable enzymic activity of the lipoprotein preparation suggests that this was obtained relatively free of contaminant casein. Moreover, the very low enzymic activity of the casein precipitate indicates that it was only slightly contaminated with lipoprotein particles.

* Present address : Department of Biochemistry, University of Melbourne, Australia.
Partial separation of the casein from the lipoprotein particles has also been obtained by removing the former as paracasein by the action of crystalline rennin. However, other methods of separation, such as by precipitation of casein at the isoelectric point, with salts or with organic solvents, result in co-precipitation of the lipoprotein particles. Hence casein prepared by these methods will always contain this lipoprotein impurity, which may account for some of the heterogeneity ascribed to so-called 'purified' casein".

The chemical and enzymic characteristics of the lipoprotein complex as shown in the table are very similar to those of the microsomal particles from animal tissues ${ }^{5}$. Therefore, it is considered that these lipoprotein particles of normal cow's milk should be called 'milk microsomes'. Furthermore, since the alkaline phosphatases of milk and of mammary gland are identical, it appears that the microsomes are released into the milk from the secretory cells of the gland. The isolation of microsomes from an animal secretion without prior homogenization or other disruptive treatment indicates that these particles occur as such in the cells.

Microsomes have been considered to be derived by fragmentation of mitochondria ${ }^{5,6}$. However, it is clear that the milk microsomes could not have been obtained in this way. The failure to demonstrate either succinic dehydrogenase or cytochrome oxidase in any of the precipitates from milk indicates that mitochondria (with which these enzymes are firmly associated) are virtually absent. They apparently are not released into milk during normal secretion. The significance of the presence of microsomes and absence of mitochondria is the subject of further investigation.

The factors which influence the release of microsomes into milk from the secretory cells of the mammary gland have not yet been studied. It seems likely, however, that more microsomes will be released during disturbance of normal functioning of the gland, as, for example, during mastitis infection, or towards the end of lactation. The alkaline phosphatase activity of milk rises under both these influences ${ }^{7,8}$. Thiouracil treatment also increases the phosphatase activity of milk ${ }^{9,10}$, in contrast to thyroxine ${ }^{11}$. It seems very probable that these compounds affect the release of the milk microsomes, rather than the phosphatase activity of the microsomes themselves. Therefore, caution is urged against concluding that the change in activity of milk is an indication of similar changes in the enzymic activity of the mammary gland itself $f^{9,10}$.

The association of xanthine oxidase activity with microsomal particles has not previously been demonstrated. It is therefore of interest that microsomes from liver have also been found to have high activity. It now seems important to determine whether the properties of the particle-bound xanthine oxidases differ from those of the flavoprotein obtained in solution either by proteolytic or lipolytic action ${ }^{12}$ or by butanol treatment'.

Electron micrographs of the casein particles and the milk microsomes have shown that both are spheroidal in shape. The microsomes, however, do not show the same tendency to clump in regular forms as do the casein particles; they are much less dense and they often appear somewhat flattened. Both types of particles vary in size, from a maximum of about $250 \mathrm{m \mu}$ diameter, diminishing beyond the limits of resolution with the equipment available (less than $30 \mathrm{~m} \mu$ ). 